University of Nebraska - Lincoln

DigitalCommons@University of Nebraska - Lincoln

Publications, Agencies and Staff of the U.S.

Department of Commerce

U.S. Department of Commerce

2009

\title{
MOVEMENTS OF SATELLITE-TAGGED CUVIER'S AND \\ BLAINVILLE'S BEAKED WHALES IN HAWAI'I: EVIDENCE FOR AN OFFSHORE POPULATION OF BLAINVILLE'S BEAKED WHALES
}

\author{
Robin W. Baird \\ Cascadia Research Collective, rwbaird@cascadiaresearch.org \\ Gregory S. Schorr \\ Cascadia Research Collective \\ Daniel L. Webster \\ Cascadia Research Collective \\ Sabre D. Mahaffy \\ Cascadia Research Collective \\ Daniel J. McSweeney \\ Wild Whale Research Foundation \\ See next page for additional authors \\ Follow this and additional works at: https://digitalcommons.unl.edu/usdeptcommercepub \\ Part of the Environmental Sciences Commons
}

Baird, Robin W.; Schorr, Gregory S.; Webster, Daniel L.; Mahaffy, Sabre D.; McSweeney, Daniel J.; Hanson, M. Bradley; and Andrews, Russel D., "MOVEMENTS OF SATELLITE-TAGGED CUVIER'S AND BLAINVILLE'S BEAKED WHALES IN HAWAI'I: EVIDENCE FOR AN OFFSHORE POPULATION OF BLAINVILLE'S BEAKED WHALES" (2009). Publications, Agencies and Staff of the U.S. Department of Commerce. 230. https://digitalcommons.unl.edu/usdeptcommercepub/230

This Article is brought to you for free and open access by the U.S. Department of Commerce at DigitalCommons@University of Nebraska - Lincoln. It has been accepted for inclusion in Publications, Agencies and Staff of the U.S. Department of Commerce by an authorized administrator of DigitalCommons@University of Nebraska - Lincoln. 


\section{Authors}

Robin W. Baird, Gregory S. Schorr, Daniel L. Webster, Sabre D. Mahaffy, Daniel J. McSweeney, M. Bradley Hanson, and Russel D. Andrews 


\title{
MOVEMENTS OF SATELLITE-TAGGED CUVIER'S AND BLAINVILLE'S BEAKED WHALES IN HAWAI'I: EVIDENCE FOR AN OFFSHORE POPULATION OF BLAINVILLE'S BEAKED WHALES
}

\section{Robin W. Baird ${ }^{1}$, Gregory S. Schorr ${ }^{1}$, Daniel L. Webster ${ }^{1}$, Sabre D. Mahaffy ${ }^{1}$, Daniel J. McSweeney ${ }^{2}$, M. Bradley Hanson ${ }^{3}$ and Russel D. Andrews ${ }^{4}$}

\author{
${ }^{1}$ Cascadia Research Collective, 218 1/2 W. $4^{\text {th }}$ Avenue, Olympia, WA 98501, U.S.A. \\ ${ }^{2}$ Wild Whale Research Foundation, Box 139, Holualoa, HI 96725 U.S.A. \\ ${ }^{3}$ NOAA, Northwest Fisheries Science Center, \\ 2725 Montlake Blvd E., Seattle, WA 98112, U.S.A. \\ ${ }^{4}$ School of Fisheries and Ocean Sciences, University of Alaska Fairbanks, \\ and Alaska SeaLife Center, 301 Railway Ave., Seward, AK 99664, U.S.A.
}

September 9, 2009

Report prepared under Contract No. AB133F-08-SE-4534

to Cascadia Research Collective, Olympia, WA from the Southwest Fisheries Science Center, National Marine Fisheries Service, La Jolla, CA 92038 USA 


\section{Report Documentation Page}

Form Approved OMB No. 0704-0188

Public reporting burden for the collection of information is estimated to average 1 hour per response, including the time for reviewing instructions, searching existing data sources, gathering and maintaining the data needed, and completing and reviewing the collection of information. Send comments regarding this burden estimate or any other aspect of this collection of information,

including suggestions for reducing this burden, to Washington Headquarters Services, Directorate for Information Operations and Reports, 1215 Jefferson Davis Highway, Suite 1204, Arlington

VA 22202-4302. Respondents should be aware that notwithstanding any other provision of law, no person shall be subject to a penalty for failing to comply with a collection of information if it

does not display a currently valid OMB control number.

\begin{tabular}{|c|c|c|}
\hline $\begin{array}{l}\text { 1. REPORT DATE } \\
09 \text { SEP } 2009\end{array}$ & 2. REPORT TYPE & $\begin{array}{l}\text { 3. DATES COVERED } \\
\text { 00-00-2009 to 00-00-2009 }\end{array}$ \\
\hline \multirow{3}{*}{\multicolumn{2}{|c|}{$\begin{array}{l}\text { Movements of Satellite-Tagged Cuvier's and Blainville's Beaked Whales } \\
\text { in Hawai'i: Evidence for an Offshore Population of Blainville's Beaked } \\
\text { Whales }\end{array}$}} & 5a. CONTRACT NUMBER \\
\hline & & 5b. GRANT NUMBER \\
\hline & & 5c. PROGRAM ELEMENT NUMBER \\
\hline \multirow{3}{*}{\multicolumn{2}{|c|}{ 6. AUTHOR(S) }} & 5d. PROJECT NUMBER \\
\hline & & 5e. TASK NUMBER \\
\hline & & 5f. WORK UNIT NUMBER \\
\hline \multicolumn{2}{|c|}{$\begin{array}{l}\text { 7. PERFORMING ORGANIZATION NAME(S) AND ADDRESS(ES) } \\
\text { Cascadia Research Collective,218 W. 4th Avenue,Olympia,WA,98501 }\end{array}$} & $\begin{array}{l}\text { 8. PERFORMING ORGANIZATION } \\
\text { REPORT NUMBER }\end{array}$ \\
\hline \multirow{2}{*}{\multicolumn{2}{|c|}{ 9. SPONSORING/MONITORING AGENCY NAME(S) AND ADDRESS(ES) }} & 10. SPONSOR/MONITOR'S ACRONYM(S) \\
\hline & & $\begin{array}{l}\text { 11. SPONSOR/MONITOR'S REPORT } \\
\text { NUMBER(S) }\end{array}$ \\
\hline
\end{tabular}

12. DISTRIBUTION/AVAILABILITY STATEMENT

Approved for public release; distribution unlimited

13. SUPPLEMENTARY NOTES 
14. ABSTRACT

The impacts of mid-frequency active sonar on the behavior of individual cetaceans may vary depending on their history of prior exposure. Evidence from habitat use, repeated sightings of identified individuals, and satellite tagging all indicate the existence of resident populations of Cuvier?s and Blainville?s beaked whales off the island of Hawai?i, within the Navy?s Hawai?i Range Complex. The number of individuals that have been satellite tagged is small however, and we are combining additional satellite tagging with individual photo-identification studies to assess movements and residency of both species. Field efforts were undertaken off the island of Hawai?i in December 2008 and April and May 2009 to examine movements and habitat use. We obtained additional movement information from one satellite tagged Cuvier?s beaked whale (36 days) and one satellite tagged Blainville?s beaked whale (40 days). The Cuvier?s beaked whale had been previously photo-identified in three different years and was linked by association with other whales from the island-associated population including three individuals satellite tagged in 2007 and 2008. During the 36 days of signal contact the whale remained strongly associated with the island, but spent the majority of its time off the east (windward) side of the island, providing the first evidence that individuals from the resident island-associated population use the windward side of the island. The tagged Blainville?s beaked whale and the other two individuals in the group had not been previously photo-identified, and were encountered further offshore $(31.3 \mathrm{~km})$ and in deeper water $(3,500$ $\mathrm{m})$ than had been documented for the island-associated population. During the first day after tagging the whale approached closer to shore, then reversed course and traveled approximately $900 \mathrm{~km}$ westward for 19 days at a median rate of horizontal movements of $2.41 \mathrm{~km} \mathrm{h-1.} \mathrm{The} \mathrm{whale} \mathrm{spent} \mathrm{the} \mathrm{last} 20$ days utilizing a broad area over $4,000 \mathrm{~m}$ deep located 900 to $1,000 \mathrm{~km}$ from the tagging location. The average depth used over the 40 days (median $=\mathbf{4 , 7 0 2} \mathrm{m}$ ) was more than three times greater than that recorded from eight previously satellite tagged Blainville?s beaked whales from the island-associated population. The lack of associations, deep-water habitat use, and movement patterns, all suggest this individual is from an open-ocean population of Blainville?s beaked whale, evidence that there may be at least two stocks of this species within the Hawaiian Exclusive Economic Zone. Genetic studies to confirm this are needed. These results also illustrate the importance of individual photoidentification to interpreting the movement patterns of individual beaked whales and potentially their responses to mid-frequency active sonar.

15. SUBJECT TERMS

16. SECURITY CLASSIFICATION OF:

a. REPORT

unclassified b. ABSTRACT unclassified
Same as unclassified
17. LIMITATION OF ABSTRACT

18. NUMBER

OF PAGES

Report (SAR) 19a. NAME OF

RESPONSIBLE PERSON 


\section{Abstract}

The impacts of mid-frequency active sonar on the behavior of individual cetaceans may vary depending on their history of prior exposure. Evidence from habitat use, repeated sightings of identified individuals, and satellite tagging all indicate the existence of resident populations of Cuvier’s and Blainville’s beaked whales off the island of Hawai ‘i, within the Navy’s Hawai ‘ Range Complex. The number of individuals that have been satellite tagged is small however, and we are combining additional satellite tagging with individual photo-identification studies to assess movements and residency of both species. Field efforts were undertaken off the island of Hawai'i in December 2008 and April and May 2009 to examine movements and habitat use. We obtained additional movement information from one satellite tagged Cuvier's beaked whale (36 days) and one satellite tagged Blainville’s beaked whale (40 days). The Cuvier's beaked whale had been previously photo-identified in three different years and was linked by association with other whales from the island-associated population including three individuals satellite tagged in 2007 and 2008. During the 36 days of signal contact the whale remained strongly associated with the island, but spent the majority of its time off the east (windward) side of the island, providing the first evidence that individuals from the resident island-associated population use the windward side of the island. The tagged Blainville's beaked whale and the other two individuals in the group had not been previously photo-identified, and were encountered further offshore (31.3 km) and in deeper water (3,500 m) than had been documented for the island-associated population. During the first day after tagging the whale approached closer to shore, then reversed course and traveled approximately $900 \mathrm{~km}$ westward for 19 days at a median rate of horizontal movements of $2.41 \mathrm{~km} \mathrm{~h}^{-1}$. The whale spent the last 20 days utilizing a broad area over 4,000 $\mathrm{m}$ deep located 900 to $1,000 \mathrm{~km}$ from the tagging location. The average depth used over the 40 days (median $=4,702 \mathrm{~m}$ ) was more than three times greater than that recorded from eight previously satellite tagged Blainville’s beaked whales from the island-associated population. The lack of associations, deep-water habitat use, and movement patterns, all suggest this individual is from an open-ocean population of Blainville's beaked whale, evidence that there may be at least two stocks of this species within the Hawaiian Exclusive Economic Zone. Genetic studies to confirm this are needed. These results also illustrate the importance of individual photoidentification to interpreting the movement patterns of individual beaked whales and potentially their responses to mid-frequency active sonar. 
Introduction

The National Marine Fisheries Service currently considers there to be a single stock each of Blainville’s beaked whales (Mesoplodon densirostris) and Cuvier's beaked whales (Ziphius cavirostris) within the Exclusive Economic Zone surrounding Hawai`i (Carretta et al. 2005). Since that assessment, information on habitat use (Baird et al. 2006), long-term site fidelity (McSweeney et al. 2007), and movements of satellite-tagged individuals (Schorr et al. 2008, 2009) have all indicated the existence of island-associated populations of both species around the island of Hawai‘i. Because of the low sighting rates, accumulation of information has been slow, and sample sizes of satellite-tagged individuals remain small: three Cuvier's beaked whales tagged for periods of 2 to 24 days and eight Blainville’s beaked whales tagged for periods of 1571 days (Schorr et al. 2008, 2009). In all cases individuals were tagged off the west side of the island of Hawai‘i and remained associated with the island for the entire duration of tag attachments. In addition, satellite data indicated limited movements around the island: all locations of the tagged Cuvier's beaked whales and the vast majority of the Blainville's beaked whales were off the west (leeward) side of the island. Based on association patterns from photoidentification, previously tagged individuals were all part of the island-associated population: at least one individual from each tagged group could be linked by association to other individuals from the island-associated population (Schorr et al. 2008, 2009).

Both Cuvier's and Blainville's beaked whales are known to be susceptible to impacts from mid-frequency active sonar (Balcomb and Claridge 2001; Jepson et al. 2003). As the impacts are likely to be behaviorally mediated (Cox et al. 2006; Hooker et al. 2009), the history of prior exposure of individuals may be important in understanding their responses to midfrequency sonar, with naïve individuals potentially showing strong behavioral responses while those exposed to mid-frequency sonar on a regular basis possibly habituating (Falcone et al. 2009a). Thus knowledge of the movement patterns and site fidelity of individuals that utilize areas where mid-frequency sonar may be used is important to assessing potential impacts. This will also be the case where individuals are instrumented with tags that may measure reactions (e.g., diving behavior, movements) during Navy exercises or controlled exposure experiments (e.g., Baird et al. 2008a; Falcone et al. 2009b; Southall et al. 2007). 
Efforts to obtain additional movement data on beaked whales in Hawaiian waters continued in December 2008 and April/May 2009. The purpose of this report is to present and discuss the results of these efforts in relation to beaked whale population structure and habitat use around the main Hawaiian Islands. In addition, we incorporate results from photoidentification of both species since the analyses of McSweeney et al. (2007) to assess whether individuals tagged are part of 'resident' island-associated populations versus from open-ocean populations.

Methods

Field operations were undertaken in December 2008 and April and May 2009 based off the west side of the island of Hawai' $\mathrm{i}$, using an $8.2 \mathrm{~m}$ Boston Whaler with a custom bowsprit and elevated tower for observations. The tagging vessel, tags and tagging system were the same as used by Schorr et al. (2008, 2009) so are only briefly discussed here. We used a Wildlife Computers (Redmond, WA) SPOT5 PTT attached with $6.5 \mathrm{~cm}$ titanium darts with backward facing petals for retention. Tags were deployed with a Dan-Inject JM Special 25 (Borkop, Denmark) pneumatic projector. With longer average dive times for Cuvier's beaked whales (Baird et al. 2006, 2008), duty cycling of the tags were set differently for each species to maximize the number of locations each day. Tags for Blainville's beaked whales were duty cycled to transmit 10 hours per day in four blocks ranging from two to three hours in duration. Tags for Cuvier's beaked whales were set to transmit 15 hours per day in five blocks ranging from two to five hours in duration. For both species the transmission periods were spread throughout the day to correspond with the periods of highest number of satellite overpasses.

For every beaked whale encounter, information was recorded on group size and location, and all individuals were photographed for individual identification and to confirm sex. Age class and sex of tagged whales and companion whales was inferred based on body size, the approximate number of cookie-cutter scars visible, the presence or absence of erupted teeth in the tip of the lower jaw, and the extent of linear scars on the body that result primarily from fighting with males (see McSweeney et al. 2007). 
Locations received from tagged whales were processed with the Douglas Argos-Filter ${ }^{1}$ to assess locations for plausibility. The filtering parameters were the same as used by Schorr et al. (2009) for satellite data obtained in 2008 (maximum-redundant-distance $=3 \mathrm{~km}$, maximum sustainable rate of movement $=10 \mathrm{~km} \mathrm{~h}^{-1}$, LC2 and LC3 locations automatically retained). Depth, slope, distance to shore, and nearest island was determined for each filtered location by overlaying point location data on a bathymetric raster surface in ArcGIS Version 9.2 (ESRI, Redlands, California, USA). Depths (in meters) were transferred to point locations using the 'intersect point tool’ in Hawth’s analysis tools (Beyer 2004). A 50 m x 50 m multibeam synthesis bathymetry model from the Hawai‘i Mapping Research Group ${ }^{2}$ was used. The model had areas of missing data, so the grid was overlaid on a 3-arc second (90 m x 90 m) U.S. Coastal Relief Model bathymetry from the National Geophysical Data Center ${ }^{3}$ to provide 90 m resolution data where $50 \mathrm{~m}$ resolution data were absent. For movements far offshore (generally $>100 \mathrm{~km}$ ) bathymetry data available to assessing depth were at $1,500 \mathrm{~m}$ x 1,500 m resolution. Filtered satellite data were overlaid on a digital bathymetry map to assess whether individuals approached seamounts. Rate of horizontal movements were calculated using intervals among consecutive locations ranging from four to 24 hours, and median values are reported, for comparison with Schorr et al. (2009).

Photographs of tagged and companion whales were compared to the catalog compiled by McSweeney et al. (2007), also including photos of each species obtained since 2006, to assess sighting history. To determine whether individuals were part of an island-associated population or possibly part of an offshore population, social network diagrams were produced for each species using Netdraw Network Visualization 2.087 (Analytic Technologies, Harvard, MA). For Blainville’s beaked whales, all distinctive and very distinctive individuals photo-identified off the island since 2000 were included. These photographs came from a variety of sources including those used in the analyses of McSweeney et al. (2007), additional photos collected in directed efforts since then, and opportunistic photos provided by other researchers or photographers. To assess the potential influence of depth of the sightings on individual resightings, for those encounters were locations were available (i.e., groups encountered in directed

\footnotetext{
${ }^{1}$ Available from http://alaska.usgs.gov/science/biology/spatial/douglas.html

${ }^{2}$ Available from http://www.soest.hawaii.edu/HMRG/Multibeam/index.php

${ }^{3}$ Available from http://www.ngdc.noaa.gov/ngdc.html
} 
efforts), depth was determined using ArcGIS as described above. To assess the likelihood of photo-identified individuals within groups having multiple records in the photo-identification database, the proportion of individuals within each group that had multiple records was calculated.

Results

Thirty-three days were spent in the field, with 238 hours of effort covering 4,247 km of trackline. During this period there were six encounters with Cuvier's beaked whales and two encounters with Blainville’s beaked whales. Satellite tags were deployed on two individual Cuvier's beaked whales and two individual Blainville's beaked whales, although only two of these four tags transmitted, one on each species.

One of the functioning tags was deployed on a lone adult female Cuvier's beaked whale (tagged April 28, 2009, photo-ID catalog \# HIZc041) initially found $5.5 \mathrm{~km}$ from shore in 1,090 m water depth. HIZc041 had been photographically documented previously off the west side of the island on three prior occasions, in October 1994, July 2007, and December 2008. A social network diagram for Cuvier's beaked whales off the island included 51 individuals that were distinctive or very distinctive with photo qualities of average or better. Of these 51 individuals, the largest cluster was 22 individuals, which included HIZc041 (Figure 1), as well as the three Cuvier’s beaked whales satellite tagged by Schorr et al. (2008).

The tag deployed on HIZc041 transmitted for 36 days and was deployed when the individual was high arching; thus the tag was lower than is optimal for obtaining satellite-derived locations. As a result the number of locations after filtering was lower than expected (43 over 24 different days). The location qualities were generally poor: there were no LC3 or LC2 locations, only three LC1 locations (7\%), and 12 LC0 locations (27.9\%). Given the animal remained in an area with very steep slopes (Figure 2), where depth varies rapidly over small areas, it is not appropriate to use the locations obtained to assess detailed habitat use (e.g., depth, slope). However, the locations were sufficient to document that the individual remained associated with the island of Hawai' $i$ for the entire duration of tag attachment. By the fourth day after tagging HIZc041 had moved from the west side of the island to the east side of the island. Although all 
subsequent locations were obtained from the east side of the island, during a five-day period where no locations were obtained it is possible HIZc041 may have moved back to the west side of the island. Based on distances between consecutive locations HIZc041 moved a minimum cumulative distance of $753 \mathrm{~km}$ during the 36 days, but moved no further than $152 \mathrm{~km}$ (straightline distance) from the location where she was originally tagged.

The other functioning tag was deployed on an adult male Blainville's beaked whale (tagged April 29, 2009, photo-ID catalog \# HIMd153) in a group of three individuals (including an adult female and a probable sub-adult male), initially located $31.3 \mathrm{~km}$ from shore in 3,500 m water depth. None of the individuals in this group had been photographically documented previously.

This tag transmitted over a 40 day span, with 110 locations on 37 days after filtering. The interval between consecutive locations ranged from $0.38 \mathrm{~h}$ to $36.43 \mathrm{~h}$ (median $=6.55 \mathrm{~h}$ ). The individual moved a cumulative minimum distance of $1,801 \mathrm{~km}$, and traveled 1,008 $\mathrm{km}$ from the site of tagging. There was a strong positive (regression, $\mathrm{r}^{2}=0.82, \mathrm{p}<0.001$ ) relationship between the time since tagging and the distance from the tagging location. Movements of HIMd153 were generally west-bound for the first 20 days of the transmission period (Figure 4). The horizontal rate of movement calculated using all pairs of consecutive locations obtained from four to 24 hours apart ranged from $0.17 \mathrm{~km} \mathrm{~h}^{-1}$ to $8.51 \mathrm{~km} \mathrm{~h}^{-1}$ (median $=1.575 \mathrm{~km} \mathrm{~h}^{-1}$ ). However, there was a significant negative relationship between the rate of movement and the time since tagging (regression, $\mathrm{r}^{2}=0.118, \mathrm{p}=0.005$ ), and during the first 20 days, the median horizontal rate of movement was $2.41 \mathrm{~km} \mathrm{~h}^{-1}$. HIMd153 utilized depths ranging from 3,150 $\mathrm{m}$ to 4,946 m (median depth $=4,702 \mathrm{~m}$ ). The closest island changed throughout the duration of tag attachment, starting with Hawai ‘ i (6 locations), Kaho'olawe (5 locations), Lana'i (2 locations), O'ahu (7 locations), Kaua 'i (2 locations), and $\mathrm{Ni}$ 'ihau (85 locations). The distance from the closest point of land ranged from $17.6 \mathrm{~km}$ to $573.0 \mathrm{~km}$ (median $=282.6 \mathrm{~km}$ ). When the tag stopped transmitting HIMd153 was $60.9 \mathrm{~km}$ from the $370 \mathrm{~km}$ EEZ boundary. After the fourth day post-tagging there were no depths associated with satellite-derived locations shallower than 3,500 m.

A social network diagram including all distinctive and very distinctive Blainville’s beaked whales photographed off the island since 2000 included 63 individuals encountered in 41 
different groups. All but 16 of these individuals were linked by association in a large social network, and all eight previously satellite tagged Blainville's beaked whales (Schorr et al. 2009) were part of this network (Figure 3). Of the remaining 16 individuals, six were seen on only a single occasion and with no other individuals, thus are not linked to any other individual. The remaining 10 individuals, including the group of three with HIMd153, were seen in four different groups. Group size of photo-identified individuals in the 41 groups ranged from 1-9. The proportion of individuals within groups that had been seen on multiple occasions ranged from 0 $-100 \%$ (median $=66.7 \%$, modal $=100 \%)$. Three groups from directed efforts were seen greater than $30 \mathrm{~km}$ from shore and in water depths $>1,500 \mathrm{~m}$. None of the eight distinctive and very distinctive individuals in these three groups have been documented on more than one occasion.

\section{Discussion}

Although data were only obtained from two individual satellite-tagged beaked whales, the results obtained provided significant new information on the movements of both Cuvier's and Blainville's beaked whales. The tagged Cuvier's beaked whale remained strongly associated with the island of Hawai ${ }^{i} i$ for the entire 36 days the tag transmitted, further supporting the suggestion that there is a resident population of Cuvier's beaked whales around the island (McSweeney et al. 2007; Schorr et al. 2008). However, unlike the three Cuvier' beaked whales previously satellite tagged off the island (Schorr et al. 2008), the individual tagged in 2009 quickly left the west side of the island and spent the majority of its time off the east side of the island (Figure 2). Given that all of the satellite tagged Cuvier's were known to be part of the same social network (Figure 1), this is the first evidence that the same individuals that utilize the west side of the island also utilize waters off the east side. This is also interesting in light of the lack of movements of eight Blainville's beaked whales tagged in 2006 and 2008 off the west side of the island to the east side (Schorr et al. 2009). Cuvier's beaked whales have been previously documented in waters of the east side of the island, primarily from aerial surveys (Mobley et al. 2000), so no information was available to assess population identity. There are two individual Cuvier's beaked whales that have been photo-identified from the east side of the island that do not match others in the catalog (Baird et al. unpublished), but poor quality photographs and the small sample size limits any conclusions based on this photographic matching. 
The information obtained from the satellite tagged Blainville's beaked whale in this study (HIMd153) substantially changes what is known of the movements of Blainville's beaked whales both in Hawai' $i$ and elsewhere. Satellite data obtained from this species in 2006 and 2008 appear to be from the resident island-associated population, with individuals remaining close to the island for the entire duration of tag attachments, over periods of weeks to months (Schorr et al. 2009). Average rate of movements of these individuals was low (1.16 $\mathrm{km} \mathrm{h}^{-1}$; Schorr et al. 2009), reflecting that their activities in the area were focused on foraging (e.g., Baird et al. 2006, 2008b), rather than travel. There is a high re-sighting rate (two thirds of all individuals within groups have been seen multiple times in the study area) of individuals seen close to shore (McSweeney et al. 2007). However, as noted by McSweeney et al. (2007), there have been some groups photo-identified in deep offshore waters off the island that do not match to any other individuals in the photo-identification catalog. This suggests the existence of both an islandassociated resident population of Blainville's beaked whales and an offshore population. The Blainville's beaked whale that we were able to satellite tag in this study was tagged $31.3 \mathrm{~km}$ offshore in water 3,500 $\mathrm{m}$ deep, and movement patterns and habitat use were unlike the previous eight satellite tagged whales, which were tagged from $2.1-20.2 \mathrm{~km}$ from shore (median $=7.2$ $\mathrm{km}$ ) in depths from 980 to 1,410 m (median =1,300 m). For Blainville's beaked whales in the Bahamas, Claridge (2004) had noted that occupancy of the best habitat for this species may be driven by a dominance hierarchy, with juvenile whales occupying deeper waters. In Hawaiian waters, with much lower density of Blainville's beaked whales (cf. Claridge 2004), we have seen no evidence of such spatial segregation (unpublished data). Claridge (2004) similarly noted that one adult male from her study population appeared to exhibit a much higher degree of site fidelity than other adult males, suggesting this was a dominant male that may exclude others from the prime habitat. In Hawai $i$, there is no evidence of a single adult male exhibiting a higher degree of site fidelity (McSweeney et al. 2007), and the tagged whale was an adult male accompanied by an adult female, so it seems unlikely the tagged whale was excluded from the near-shore habitat by dominance interactions. Whether there are two or more different stocks as defined under the Marine Mammal Protection Act will require confirmation through genetic studies or evidence regarding the recruitment of calves into the population in which they were born. 
For the first 20 days after tagging the average rate of horizontal movements was more than twice as high (median $=2.41 \mathrm{~km} \mathrm{~h}^{-1}$ ) as found for the previously satellite tagged Blainville's beaked whales (Schorr et al. 2009). Although the tagged whale moved to within $17.6 \mathrm{~km}$ of shore (and a depth of 3,150 m) during the first day after tagging, it then proceeded to swim generally west-ward for approximately 18 days, moving over $900 \mathrm{~km}$ from the site where it was tagged. The median depth of locations of the tagged whale was 4,702 $\mathrm{m}$, in comparison to the average depth of 1,156 m used by previously tagged Blainville’s beaked whales off the island (Schorr et al. 2009). With only 40 days of movements of one individual it is not possible to assess the range of individuals in the offshore population. Given the wide ranging movement in this relatively short period however, it is likely that individuals from this population move over much wider areas likely including both U.S. and international waters. Such wide-ranging movements is relevant to assessing the potential for repeated exposure to high-intensity midfrequency sonars associated with Naval exercises, since individuals moving through the area on a rare occasion are likely to have not been previously exposed, whereas individuals in the resident island-associated population may have had considerable prior exposure to sonar. It is likely that reactions to sonar vary with prior exposure, which could include changes in tolerance, or either habituation or sensitization (cf. Bejder et al. 2009). This also illustrates the importance of individual photo-identification to interpreting movement patterns and behavior of individual beaked whales. In recent years there have been several attempts to instrument beaked whales with tags that will record or transmit behavior or locations in association with controlled exposure experiments or Navy exercises (Southall et al. 2007; Baird et al. 2008a; Falcone et al. 2009b), but interpreting potentially reactive behavior or movements requires a baseline and understanding of normal behavior and movement patterns.

\section{Acknowledgements}

Funding for field work was from the U.S. Navy through a contract from the National Marine Fisheries Service as well as contracts from the Scripps Institution of Oceanography and the Alaska SeaLife Center. Additional support was received from the Wild Whale Research Foundation. Tagging was undertaken under NMFS Scientific Research Permit No. 731 (issued to RWB). 


\section{Literature Cited}

Baird, R.W., D.L. Webster, D.J. Mcsweeney, A.D. Ligon, G.S. Schorr, and J. Barlow. 2006. Diving behaviour of Cuvier's (Ziphius cavirostris) and Blainville's (Mesoplodon densirostris) beaked whales in Hawai'i. Canadian Journal of Zoology 84:1120-1128.

Baird, R.W., G.S. Schorr, D.L. Webster, D.J. McSweeney, M.B. Hanson, and R.D. Andrews. 2008a. Multi-species cetacean satellite tagging to examine movements in relation to the 2008 Rim-of-the-Pacific (RIMPAC) naval exercise. A quick look report on the results of tagging efforts undertaken under Order No. D1000115 from the Woods Hole Oceanographic Institution. Available from www.cascadiaresearch.org/robin/hawaii.htm

Baird, R.W., D.L. Webster, G.S. Schorr, D.J. McSweeney and J. Barlow. 2008b. Diel variation in beaked whale diving behavior. Marine Mammal Science 24:630-642.

Balcomb, K.C., and D.E. Claridge. 2001. A mass stranding of cetaceans caused by naval sonar in the Bahamas. Bahamas Journal of Science 5:1-12.

Bejder, L., A. Samuels, H. Whitehead, H. Finn, and S. Allen. 2009. Impact assessment research: use and misuse of habituation, sensitisation and tolerance in describing wildlife responses to anthropogenic stimuli. Marine Ecology Progress Series doi: 10.3354/meps07979.

Carretta, J.V., K.A. Forney, M.M. Muto, J. Barlow, J. Baker, B. Hanson and M.S. Lowry. 2005. U.S. Pacific marine mammal stock assessments: 2004. NOAA Technical Memorandum NOAA-TM-NMFS-SWFSC-375.

Claridge, D.E. 2004. Fine-scale distribution and habitat use of beaked whales. M.Sc.Thesis, University of Aberdeen, Scotland.

Cox ,T.M., T.J. Ragen, A.J. Read, E. Vos, R.W. Baird, K. Balcomb, J. Barlow, J. Caldwell, T. Cranford, L. Crum, A. D’amico, G. D’spain, A. Fernández, J. Finneran, R. Gentry, W. Gerth, F. Gulland, J. Hildebrand, D. Houser, T. Hullar, P.D. Jepson, D. Ketten, C.D. Macleod, P. Miller, S. Moore, D. Mountain, D. Palka, P. Ponganis, S. Rommel, T. Rowles, B. Taylor, P. Tyack, D. Wartzok, R. Gisiner, J. Mead, and L. Benner. 2006. Understanding the impacts of anthropogenic sound on beaked whales' Journal of Cetacean Research and Management 7:177-187.

Falcone, E.A., G.S. Schorr, A.B. Douglas, J. Calambokidis, E. Henderson, M.F. McKenna, J. Hildebrand, and D. Moretti. 2009a. Sighting characteristics and photo-identification of Cuvier's beaked whales (Ziphius cavirostris) near San Clemente Island, California: a key area for beaked whales and the military? Marine Biology doi 10.1007/s00227-009-12898.

Falcone, E.A., G.S. Schorr, A.B. Douglas, D.L. Webster, J. Calambokidis, J. Hildebrand, R.D. Andrews, M.B. Hanson, R.W. Baird, and D. Moretti. 2009b. Movements of Cuvier's beaked whales in a region of frequent naval activity: Insights from sighting, photo- 
identification, and satellite tag data. Abstract submitted to the $18^{\text {th }}$ Biennial Conference on the Biology of Marine Mammals, Quebec, October 2009.

Hooker, S.K., R.W. Baird, and A. Fahlman. 2009. Could beaked whales get the bends? Effects of diving behaviour and physiology on modelled gas exchange for three species: Ziphius cavirostris, Mesoplodon densirostris and Hyperoodon ampullatus. Respiratory Physiology \& Neurobiology 167:235-246.

Jepson, P.D., M. Arbelo, R. Deaville, I.A.P. Patterson, P. Castro, J.R. Baker, E. Degollada, H.M. Ross, P. Herraez, A.M. Pocknell, F. Rodriguez, F.E. Howie, A. Espinosa, R.J. Reid, J.R. Jaber, V. Martin, A.A. Cunningham, and A. Fernandez. 2003. Gas-bubble lesions in stranded cetaceans: Was sonar responsible for a spate of whale deaths after an Atlantic military exercise? Nature (London) 425:575-576.

McSweeney, D.J., R.W. Baird, and S.D. Mahaffy. 2007. Site fidelity, associations and movements of Cuvier's (Ziphius cavirostris) and Blainville's (Mesoplodon densirostris) beaked whales off the island of Hawai'i. Marine Mammal Science 23:666-687.

Mobley, J.R., S.S. Spitz, K.A. Forney, R. Grotefendt and P.H. Forestell. 2000. Distribution and abundance of odontocete species in Hawaiian waters: Preliminary results of 1993-98 aerial surveys. SWFSC administrative report LJ-00-14C, 27pp.

Schorr, G.S., R.W. Baird, M.B. Hanson, D.L. Webster, D.J. McSweeney, and R.D. Andrews. 2008. Movements of the first satellite-tagged Cuvier's and Blainville's beaked whales in Hawai‘i. Report prepared under Contract No. AB133F-07-SE-3706 to Cascadia Research Collective, Olympia, WA from the Southwest Fisheries Science Center, National Marine Fisheries Service, La Jolla, California. Available from www.cascadiaresearch.org/robin/hawaii.htm

Schorr, G.S., R.W. Baird, M.B. Hanson, D.L. Webster, D.J. McSweeney and R.D. Andrews. 2009. Movements of satellite-tagged Blainville's beaked whales off the island of Hawai'i. Endangered Species Research in press.

Southall, B., I. Boyd, P. Tyack, and D. Wartzok. 2007. Deep-diving odontocetes behavioral response study (BRS). Presentation at the conference on the effects of noise on aquatic life, Nyborg, Denmark, August 13-17, 2007. 


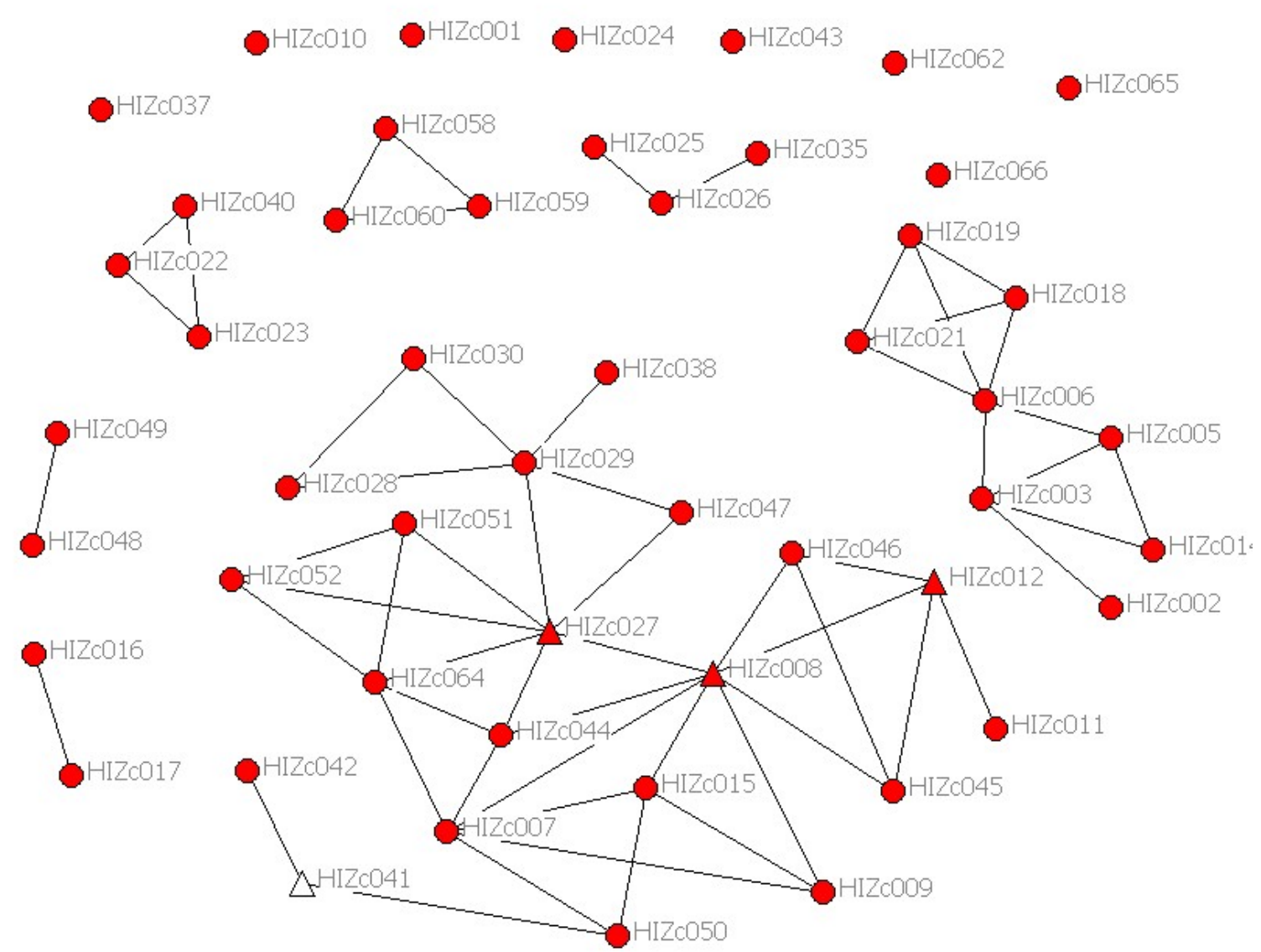

Figure 1. A social network diagram of Cuvier's beaked whales photo-identified off the island of Hawai'i, from 1990 through May 2009, including distinctive and very distinctive individuals with photo qualities of average or better (see McSweeney et al. 2007). All four individuals from which satellite-derived locations have been obtained are linked in a single social network. Satellite tagged individuals from Schorr et al. (2008) are indicated in red triangles. HIZc041 (this study) is indicated by an open triangle. The relatively small number of individuals in the largest cluster reflect the small average group size (median $=2$ ), and the large number of individuals with no links to others reflects the large number of lone individuals encountered. 


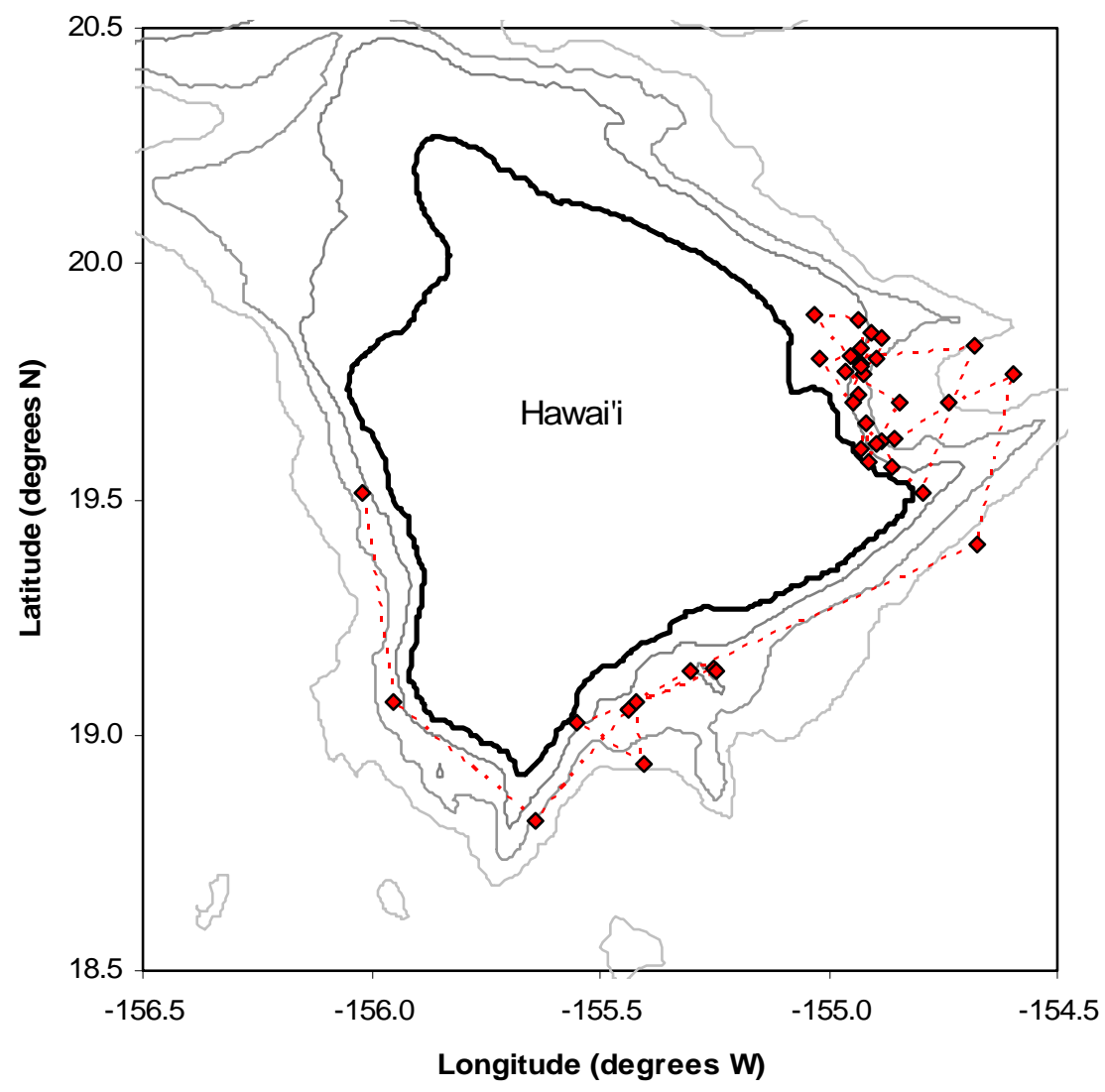

Figure 2. Map showing satellite derived locations of the tagged Cuvier's beaked whale (HIZc041) with consecutive locations joined by a red dashed line. The 1,000, 2,000 and 3,000 m depth contours are shown. Locations on land were removed. Note the relatively poor-quality locations for this individual suggest that the locations shown should only be considered approximate. 


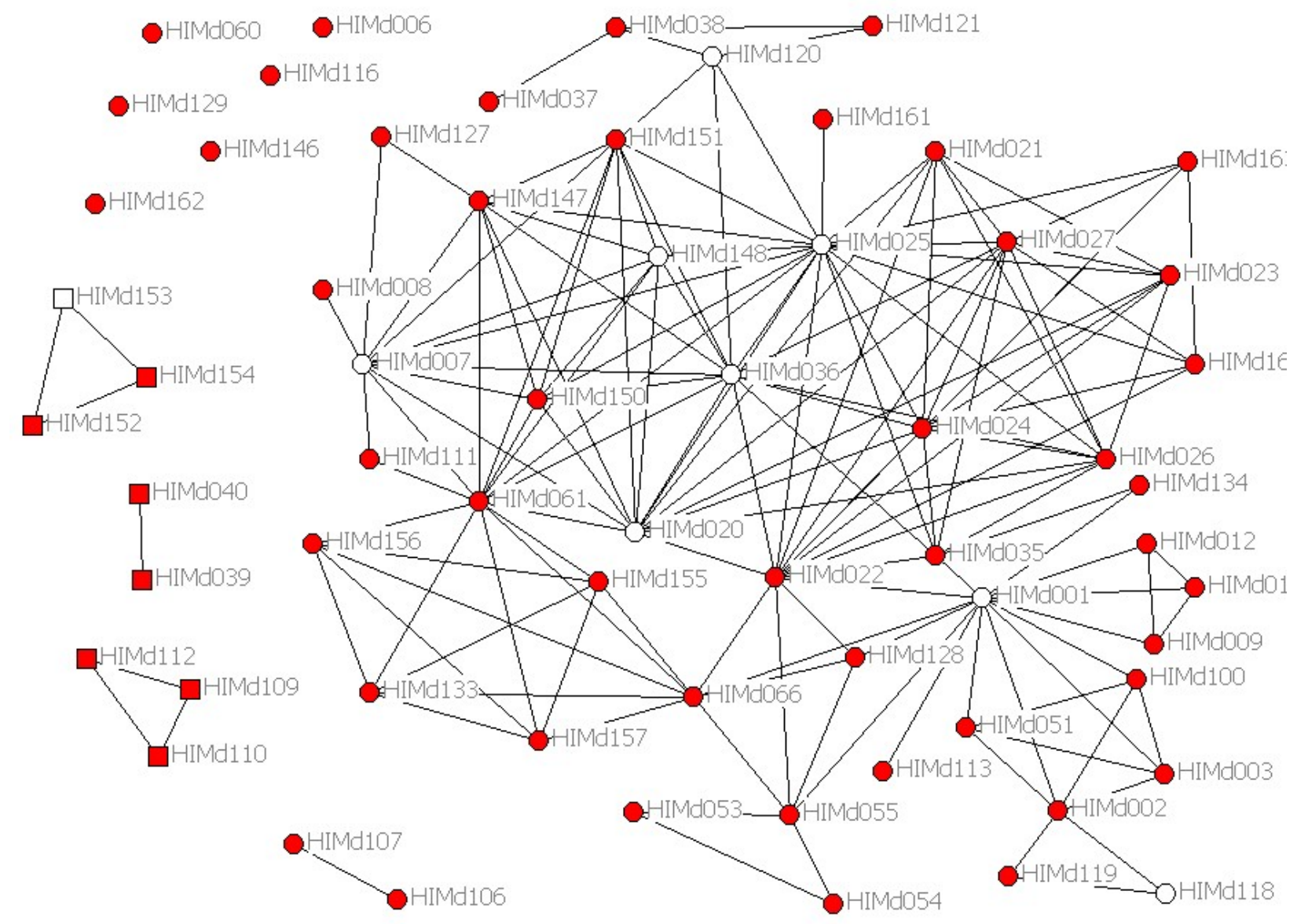

Figure 3. A social network diagram of all distinctive and very distinctive Blainville’s beaked whales photo-identified off the island of Hawai' $i$ since 2000. All individuals satellite tagged prior to December 2008 are indicated by open circles (see Schorr et al. 2008, 2009), the tagged individual in this study (HIMd153) is indicated by an open square. Individuals for which depth information is available found greater than $30 \mathrm{~km}$ from shore and in greater than 1,500 m of water are indicated by squares; all others are indicated by circles. 

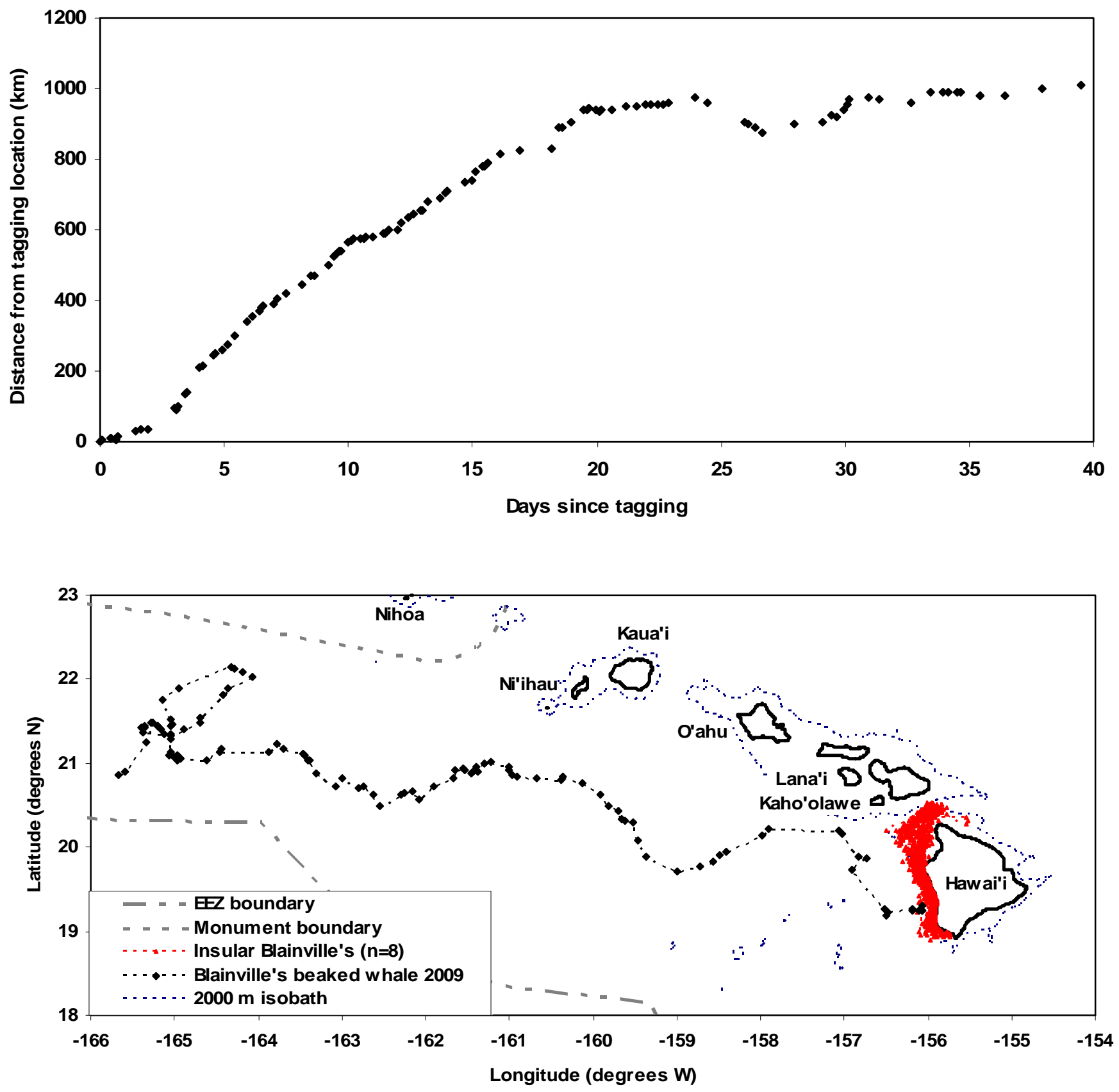

Figure 4. Top. Distance from tagging location over time for satellite tagged Blainville's beaked whale HIMd153. Bottom. Map showing locations of HIMd153 from 2009 as well as the locations of eight tagged Blainville’s beaked whales from 2006 and 2008 (from Schorr et al. 2009). The 2,000 $\mathrm{m}$ isobath, the U.S. EEZ boundary, and the boundary of the Papahānaumokuākea National Marine Monument are shown. 